\title{
ANALISA LAPORAN KEUANGAN BERDASARKAN RASIO RENTABILITAS PADA PT. BPD SUMATERA BARAT TAHUN $2013-2015$
}

\author{
Sinta Dwi Lestari, Jhon Fernos \\ Akademi Keuangan Perbankan "Pembangunan" Padang \\ Jhonfernos@akbpstie.ac.id
}

\begin{abstract}
Management effectiveness from 2013 to 2014 and 2015 decreased significantly, especially on ROA to below BI standards. The company's ability to generate net income in 2013 showed good ability compared to 2014 and 2015 which experienced a significant decline from the previous year. The company's ability to generate profits from operating return on capital in 2013, 2014 and 2015 was very efficient because the value of ROE in 2013, 2014 and 2015 was above the standards of Bank Indonesia. Improve management ability to be more effective in managing the company's own capital. Future profit planning evaluation needs to be done, as well as new management replacements, especially after the old management has failed. If the ROA of a Bank is not progressing in the next period, Bank Indonesia should warn or give firmness to the Bank in order to be able to manage its assets properly. , so that the Bank's ROA can reach Bank Indonesia standards, the percentage of which is 5.08\%.
\end{abstract}

Keywords: Bank, Rentability, Financial Ratio

\section{PENDAHULUAN}

Lembaga keuangan perbankan merupakan lembaga keuangan yang bertugas menghimpun dana dari masyarakat dan menyalurkan kembali kembali ke masyarakat guna memenuhi kebutuhan dana bagi pihak yang membutuhkan, baik untuk kegiatan produktif maupun konsumtif. Untuk menjalankan tugas tersebut, bank harus memiliki tingkat kesehatan yang baik sehingga dapat menjalankan fungsi - fungsi bank salah satunya mendapatkan serta memelihara kepercayaan masyarakat.

Bank sebagai lembaga keuangan berfungsi sebagai financial intermediary atau perantara keuang-an dari dua pihak yakni pihak yang kelebihan dana dan pihak yang kekurangan dan atau membtuhkan dana. Selain itu, sebagai institusi yang amat penting peranannya dalam masyarakat, bank adalah suatu lembaga keuangan yang usaha pokoknya memberikan kredit dan jasa- jasa dalam lalu lintas pembayaran dan peredaran uang. Bank menerima simpanan uang masyarakat dalam bentuk deposito dan tabungan kemudian uang tersebut dikembalikan lagi kemasyarkat dalam bentuk kredit. Kegiatan dalam usaha dunia perbankan tidak terlepas dari pemilik bank, manajemen bank itu sendiri, investor, nasabah, pemerintah dan karyawan sangat membutuhkan informasi tentang keuangan perbankan itu sendiri. Informasi keuangan tersebut dapat diketahui dari laporan keuangan bank tersebut. Laporan keuangan akan memberikan gambaran kelemahan dan kekuatan keuangan perusahaan dari tahun ke tahun.

Laporan keuangan adalah dua daftar yang disusun oleh akuntan pada akhir periode untuk suatu perusahaan. Kedua daftar itu adalah daftar neraca atau daftar periode keuangan dan daftar pendapatan atau daftar laba- rugi. Laporan keuangan merupakan sumber informasi yang penting untuk mengetahui dan menganalisis keadaan 
keuangan suatu bank. Agar laporan keuangan dapat dibaca sehingga menjadi berarti, perlu dilakukan analisis terlebih dahulu. Analisa yang digunakan adalah dengan menggunakan rasio - rasio keuangan bank sesuai dengan standar yang berlaku, salah satu rasio yang digunakan adalah rasio rentabilitas.

Rasio adalah suatu angka yang menunjukkan hubungan antara suatu unsur dengan lainnya dalam laporan keuangan. Menurut Harahap (2002 : 298), memberikan batasan sebagai berikut : "Rasio keuangan adalah angka yang diperoleh dari hasil perbandingan dari satu pos laporan keuangan dengan pos lainnya yang mempunyai hubungan yang relevan dan signifikan (berarti)".

Rasio Rentabilitas adalah rasio yang menunjukkan kemampuan perusahaan untuk menghasilkan laba selama periode tertentu.

Rasio rentabilitas dapat diukur dengan beberapa indikator, diantaranya :

1. Net Profit Margin (NPM)

Merupakan kemampuan perusahaan dalam menghasilkan keuntungan dibandingkan dengan penjualan yang dicapai.

2. Return On Asset (ROA)

Sering disebut sebagai rentabilitas ekonomis yaitu merupakan kemampuan perusahaan dalam menghasilkan laba dengan semua aktiva yang dimiliki oleh perusahaan.

3. Return On Equity (ROE)

Sering disebut dengan rentabilitas modal sendiri, merupakan kemampuan perusahaan dalam menghasilkan keuntungan dengan modal sendiri yang dimiliki.

Rentabilitas suatu perusahaan diukur dengan kesuksesan perusahaan dan kemampuan menggunakan aktivanya secara produktif, dengan demikian rentabilitas suatu perusahaan dapat diketahui dengan memperbandingkan antara laba yang diperoleh dalam suatu periode dengan jumlah aktiva atau jumlah modal perusahaan tersebut. Bagi seorang kreditur yang terpenting adalah faktor rentabilitas, karena rentabilitas merupakan jaminan yang utama bagi para kreditur tanpa mengabaikan faktor lainnya. Berapapun besarnya likuiditas suatu perusahaan, apabila perusahaan tersebut tidak mampu menggunakan modalnya secara efisien atau tidak mampu memperoleh laba yang besar, maka perusahaan tersebut pada akhirnya akan mengalami kesulitan keuangan dalam mengembalikan hutang - hutangnya.

PT. BPD Sumatera Barat merupakan salah satu bank pembangunan daerah yang memberikan bantuan modal kepada pengusaha - pengusaha kecil yang ada di pedesaan dan diharapkan dengan bantuan modal ini pengusaha - pengusaha kecil tersebut dapat memanfaatkan modal yang diberikan untuk menjalankan usahanya dengan baik. Sektorsektor yang dapat dibiayai dengan kredit oleh PT. BPD Sumatera Barat adalah semua usaha yang dapat menghasilkan barang dan jasa seperti pertanian, perikanan, peternakan, perdagangan, jasa dan industri kecil.

PT. BPD Sumatera Barat dituntut untuk berperan sebagai pengantisipasian kebiasaan masyarakat yang bias meminjam uang pada para rentenir dan tengkulak dengan bunga yang begitu tinggi, sehingga perekonomian masyarakat semakin memburuk. Dengan adanya PT. BPD Sumatera Barat ini maka masyarakat dapat terlepas dari cengkraman para rentenir dan tengkulak, karena tujuan utama dari PT. BPD Sumatera Barat adalah menyalurkan dana dan menghimpun dana dari masyarakat sehingga dapat menunjang perekonomian rakyat. 
Tabel 1

Perkembangan Rentabilitas

PT. BPD Sumatera Barat

Tahun 2013-2015

\begin{tabular}{lccc}
\hline \multirow{2}{c}{ Keterangan } & \multicolumn{3}{c}{ Tahun } \\
\cline { 2 - 4 } & 2013 & 2014 & 2015 \\
\hline Net Profit Margin (NPM) & $16,85 \%$ & $14,13 \%$ & $14,00 \%$ \\
Return On Asset (ROA) & $2,65 \%$ & $1,93 \%$ & $2,29 \%$ \\
Return On Equity (ROE) & $15,63 \%$ & $14,68 \%$ & $15,86 \%$ \\
\hline
\end{tabular}

Sumber : Data hasil olahan

Dari tabel 1. diatas menunjukkan bahwa NPM PT. BPD Sumatera Barat pada tahun 2013 sebesar 16,85\%, tahun 2014 sebesar 14,13\% dan tahun 2015 sebesar 14,00\% yang diperoleh dari laba bersih setelah pajak dibagi dengan penjualan bersih (pendapatan), dimana laba bersih setelah pajak tahun $2013 \mathrm{Rp} 312.725$, tahun $2014 \mathrm{Rp}$ 293.793, dan tahun $2015 \mathrm{Rp} 317.279$. Sedangkan total penjualan bersih tahun $2013 \mathrm{Rp}$ 1.855.250, tahun 2014 Rp 2.078.547 dan tahun 2015 Rp 2.265.374.

Untuk ROA pada tahun 2013 sebesar 2,65\%, tahun 2014 sebesar 1,93\%, dan tahun 2015 sebesar 2,29\% yang diperoleh dari laba sebelum pajak dibagi dengan total asset, dimana laba sebelum pajak tahun 2013 Rp 432.321, tahun 2014 Rp 348.247 dan tahun $2015 \mathrm{Rp}$ 446.825. Sedangkan untuk total asset tahun $2013 \mathrm{Rp} 16.244 .113$, tahun 2014 Rp 18.014.579, dan tahun 2015 Rp 19.448.300.

Dan untuk ROE pada tahun 2013 sebesar 15,63\% tahun 2014 sebesar 14,68\% dan tahun 2015 sebesar 15,86\% yang diperoleh dari laba bersih setelah pajak dibagi dengan modal sendiri, dimana laba bersih setelah pajak pada tahun $2013 \mathrm{Rp} 312.725$, tahun 2014 Rp 293.793, dan tahun 2015 Rp 317.279. Sedangkan untuk modal sendiri tahun 2013 Rp 2.000.000, tahun 2014 Rp 2.000.000 dan tahun 2015 Rp 2.000.000.

Dari pengelolaan dana yang dilakukan oleh PT. BPD Sumatera Barat dapat dinilai tingkat kesehatan bank tersebut. Dimana perlu dilakukan penilaian terhadap faktor - faktor yang menentukan tingkat kesehatan bank. Dari uraian diatas, penulis tertarik untuk mengetahui bagaimana kemampuan PT. BPD Sumatera Barat dalam menggunakan modalnya secara serta efisien serta menggunakan aktivanya secara produktif untuk menghasilkan laba selama periode tertentu dengan tujuan perusahaan tersebut dapat beroperasi secara stabil dan mampu mengembalikan semua hutang hutangnya kepada pihak lain. Maka penulis berkeinginan untuk menganalisis laporan keuangan PT. BPD Sumatera Barat. Untuk itu, penulis memberikan judul proposal ini dengan "Analisa Laporan Keuangan Berdasarkan Rasio Rentabilitas Pada PT. BPD Sumatera Barat Tahun 2013 - 2015".

Berdasarkan latar belakang diatas, maka penulis dapat merumuskan masalah tentang : Bagaimanakah Analisa Laporan Keuangan Berdasarkan Rasio Rentabilitas Pada PT. BPD Sumatera Barat 


\section{LANDASAN TEORI Pengertian Bank}

Bank merupakan salah satu lembaga keuangan yang mempunyai peranan penting di dalam perekonomian suatu Negara sebagai lembaga perantara keuangan. Bank dalam pasal 1 ayat (2) UU No. 10 Tahun 1998 tentang perubahan UU No. 7 Tahun 1992 tentang perbankan adalah badan usaha yang menghimpun dana dari masyarakat dalam bentuk simpanan dan menyalurkannya kepada masyarakat dalam bentuk kredit dan atau bentuk-bentuk lain dalam rangka meningkatkan taraf hidup rakyat banyak.

Bank dapat dibedakan dalam beberapa jenis yaitu :

1. Bank Sentral

Bank Sentral adalah Bank yang tugasnya mengeluarkan uang kertas serta uang logam untuk alat pembayaran sah di sebuah Negara. Tugas lainnya adalah menjaga konversi uang terhadap nilai emas dan perak.

2. Bank Umum

Bank Umum adalah institusi keuangan yang berwenang memberikan pinjaman atau melakukan investasi dari dana tabungan yang berhasil dihimpunnya, namun juga bisa memberikan pinjaman dengan mengeluarkan sendiri yang dinamakan uang giral.

3. Bank Perkreditan Rakyat (BPR)

Bank Perkreditan Rakyat adalah bank yang menjalankan usahanya scara tradisional atau bisa juga dengan mendasarkannya pada kaidah islam dimana aktifitasnya tak menyediakan jasa pada lalu lintas pembayaran.

4. Bank Syariah

Bank yang bekerja sesuai dengan kaidah bagi hasil yang sejalan dengan prinsip islami mengenai hukum riba.

\section{Fungsi Bank}

Fungsi bank secara umum adalah menghimpun dana dari masyarkat luas (funding) dan menyalurkan dalam bentuk pinjaman atau kredit (lending) untuk berbagai tujuan. Tetapi sebenarnya fungsi bank dapat dijelaskan dengan lebih spesifik seperti yang diungkapkan oleh Y. Sri Susilo, Sigit Triandaru, dan A. Totok Budi Santoso (2006), yaitu sebagai berikut :

\section{Agent Of Trust}

Dasar utama kegiatan perbankan adalah trust atau kepercayaan, baik dalam hal menghimpun dana maupun penyaluran dana.

2. Agen Of Development

Kelancaran kegiatan investasi, distribusi, konsumsi ini tidak lain adalah kegiatan pembangunan perekonomian masyarakat.

3. Agent Of Service

Selain menghimpun dan menyalurkan dana, bank juga memberikan penawaran jasajasa perbankan yang lain kepada masyarakat seperti jasa pengiriman uang, jasa penitipan barang berharga dan lain-lain.

\section{Pengertian Laporan Keuangan}

Laporan keuangan adalah laporan yang menunjukkan kondisi keuangan perusahaan pada saat ini atau dalam suatu periode tertentu. (Kasmir, 2008 : 7). Laporan keuangan merupakan hasil akhir dari suatu proses pencatatan, yang merupakan suatu 
ringkasan dari transaksi-transaksi keuangan yang terjadi selama tahun buku yang bersangkutan.

Menurut Kasmir ( 2008:10 ), secara umum laporan keuangan bertujuan untuk memberikan informasi keuangan suatu perusahaan, baik pada saat tertentu maupun pada periode tertentu. Berikut ini beberapa tujuan pembuatan atau penyusunan laporan keuangan, yaitu :

1. Memberikan informasi tentang jenis dan jumlah aktiva (harta) yang dimiliki perusahaan pada saat ini;

2. Memberikan informasi tentang jenis dan jumlah kewajiban dan modal yang dimiliki perusahaan saat ini;

3. Memberikan informasi tentang jenis dan jumlah pendapatan yang diperoleh pada suatu periode tertentu;

4. Memberikan informasi tentang jumlah biaya dan jenis biaya yang dikeluarkan perusahaan dalam suatu periode tertentu;

5. Memberikan informasi tentang perubahan-perubahan yang terjadi atas aktiva, pasiva, dan modal perusahaan;

6. Memberikan informasi tentang kinerja manajemen perusahaan dalam suatu periode;

7. Memberikan informasi tentang catatan-catatan atas laporan keuangan;

8. Informasi keuangan lainnya;

\section{Bentuk-Bentuk Laporan Keuangan}

Ada banyak laporan keuangan yang dikeluarkan perusahaan, tetapi yang umum digunakan adalah :

1. Laporan Laba Rugi

Munawir mendefinisikan laporan rugi laba adalah :'Laporan rugi laba merupakan suatu laporan yang sistematis tentang penghasilan, biaya, rugi laba yang diperoleh organisasi suatu perusahaan selama periode tertentu". $(2000: 26)$

2. Neraca

Munawir menyatakan bahwa : "Neraca adalah laporan yang sistematis tentang aktiva, hutang serta modal dari suatu laporan yang disusun pada suatu saat tertentu". (2000 : 13) Menurut Harnanto, neraca adalah :"Suatu laporan yang disusun dengan maksud untuk menunjukkan keadaan (posisi) finansial perusahaan pada saat tanggal tertentu". (1984 : I) Bentuk neraca yang ada pada perusahaanperusahaan tidak ada yang seragam, bentuk dan susunannya tergantung pada tujuan yang akan dicapai. Bentuk neraca yang lazim digunakan adalah sebagai berikut :

a. Bentuk skontro, dimana semua aktiva tercantum sebelah kiri/debet dan hutang serta modal tercantum sebelah kanan/kredit.

b. Bentuk vertikal, dalam bentuk ini semua aktiva Nampak dibagian atas yang selanjutnya diikuti hutang jangka pendek, hutang jangka panjang serta modal.

3. Laporan Perubahan Laba Ditahan

Laporan perubahan laba ditahan menunjukkan laba yang diperoleh perusahaan dan deviden yang dibayarkan selama satu periode sehingga menyebabkan perubahan laba ditahan.

4. Laporan Arus Kas

Laporan arus kas merupakan ringkasan arus kas selama satu periode. Laporan ini menunjukkan perubahan arus kas yang terjadi karena kegiatan operasi, investasi dan financial sehingga posisi/saldo kas berubah.

Tujuan yang paling utama dari laporan arus kas ini adalah untuk memberikan informasi penting atau yang relevan mengenai penerimaan-penerimaan dan 
pengeluaran-pengeluaran kas selama periode berjalan. Adapun bentuk penyajian laporan arus kas ini dibagi menjadi empat, yakni :

a. Diklasifikasikan berdasarkan aktivitas operasi seperti penjualan tunai, pelunasan hutang, pembayaran biaya-biayanya.

b. Diklasifikasikan berdasarkan aktivitas investasi seperti menginvestasikan dana yang tidak terpakai.

c. Diklasifikasikan berdasarkan aktivitas pendanaan seperti dana pinjaman dari luar perusahaan (Hutang jangka panjang).

d. Disesuaikan dengan bisnis perusahaan

\section{Pengertian Analisa Laporan Keuangan}

Munawir mengemukakan pengertian analisa laporan keuangan adalah "Mempelajari hubungan-hubungan di dalam suatu setiap laporan keuangan pada suatu saat tertentu dan kecenderungan-kecenderungan dari hubungan ini sepanjang waktu". (1998)

Menurut Harahap analisa laporan keuangan yaitu "menguraikan pos-pos laporan keuangan menjadi unit informasi yang lebih kecil dan melihat hubungan yang bersifat signifikan atau yang mempunyai makna antara satu dengan yang lain baik antaradata kuantitatif maupun non kuantitatif dengan tujuan untuk mengetahui kondisi keuangan lebih dalam yang sangat penting dalam proses menghasilkan keputusan yang tepat".(1998:3)

Menurut Djahidin analisa laporan keuangan adalah "Analisa laporan keuangan yang mencakup penerapan metode dari teknik analitis atas laporan keuangan dan data lainnya untuk melihat dari laporan itu ukuran-ukuran dan hubungan tertentu yang sangat berguna dalam proses pengambilan keputusan". (1983).

\section{Tujuan Analisa Laporan}

Berikut ini tujuan dari analisa laporan keuangan, yaitu :

a. Untuk mengetahui posisi keuangan perusahaan dalam satu periode tertentu;

b. Untuk mngetahui kelemahan-kelemahan perusahaan;

c. Untuk mengetahui kekuatan-kekuatan yang dimiliki;

d. untuk mengetahui langkah-langkah perbaikan apa saja yang perlu dilakukan untuk penilaian kinerja manajemen.

\section{METODE PENELITIAN}

Dalam pengumpulan data dan bahan untuk melakukan penelitian ini, digunakan metode - metode pengumpulan data sebagai berikut :

1. Metode Pengumpulan Data

a. Studi Lapangan (Field Research)

Peninjauan langsung ke objek penelitian dipilih untuk meneliti hasil data primer dan membantu penulis melengkapi data yang diperlukan. Adapun cara riset ini adalah dengan mewawancarai pihak - pihak yang berkepentingan dalam hal ini adalah perusahaan atau instansi yang terkait.

b. Studi Kepustakaan (Library Research)

Penilaian yang dilakukan ke perpustakaan beberapa buku - buku ilmiah dan tulisan - tulisan yang berhubungan dengan pembahasan yang dilakukan.

2. Metode Analisa Data

Dalam menganalisa data, penulis menggunakan analisis data kuantitatif sebagai metode penelitian yang menjelaskan secara deskriptif mengenai bagaimana analisa laporan keuangan pada PT. BPD Sumatera Barat. Metode analisis ditinjau dari dua 
segi yang berbeda yaitu antara teori dan praktek yang perlu diterapkan, sehingga dapat diketahui sejauh mana pelaksanaannya, apakah perbedaan yang timbul menyangkut prinsip dasar konsep itu sendiri, pertanyaan itu akan terjawab, selanjutnya dari hasil analisa itu digunakan sebagai dasar pengambilan kesimpulan dan saran.

\section{HASIL DAN PEMBAHASAN}

1. Net Profit Margin

Net profit margin adalah rasio yang membandingkan antara laba setelah bunga dan pajak dan penjualan bersih untuk menunjukkan berapa bagian dari penjualan bersih yang menjadi laba setelah bunga dan pajak. Semakin tinggi rasio ini semakin menguntungkan karena laba bersih perusahaan semakin besar.

Table 2

Perkembangan Net Profit Margin

PT. Bank Pembangunan Daerah Sumatera Barat

Tahun 2013-2015

\begin{tabular}{cccc}
\hline Tahun & Laba Bersih Setelah Pajak & $\begin{array}{c}\text { Penjualan Bersih } \\
(1)\end{array}$ & $\begin{array}{c}\text { Net Profit Margin } \\
(1: 2) \times 100 \%\end{array}$ \\
\hline 2013 & Rp 312.725 & Rp 1.855.250 & $16,85 \%$ \\
2014 & Rp 293.793 & Rp 2.078.547 & $14,13 \%$ \\
2015 & Rp 317.279 & Rp 2.265.374 & $14,00 \%$ \\
\hline
\end{tabular}

Sumber : Data Hasil Olahan

2. Return On Asset

Sering disebut sebagai rentabilitas ekonomis yaitu kemampuan perusahaan dalam menghasilkan laba dengan semua aktiva yang dimiliki oleh perusahaan.

Table 3

Perkembangan Return On Asset

PT. BPD Sumatera Barat

Tahun 2013-2015

\begin{tabular}{cccc}
\hline Tahun & $\begin{array}{c}\text { Laba Sebelum Pajak } \\
(1)\end{array}$ & $\begin{array}{c}\text { Total Asset } \\
(2)\end{array}$ & $\begin{array}{c}\text { Return On Asset } \\
(1: 2) \times 100 \%\end{array}$ \\
\hline 2013 & $\operatorname{Rp~432.321}$ & Rp 16.244.113 & $2,65 \%$ \\
2014 & $\operatorname{Rp~348.247}$ & Rp 18.014.579 & $1,93 \%$ \\
2015 & $\operatorname{Rp~446.825}$ & Rp 19.448.300 & $2,29 \%$ \\
\hline
\end{tabular}

Sumber : Data Hasil Olahan

\section{Return On Equity}

ROE sering juga disebut sebagai rentabilitas modal sendiri yaitu merupakan kemampuan perusahaan dalam menghasilkan keuntungan dengan modal sendiri yang dimiliki. 
Table 4

Perkembangan Return On Equity

PT. BPD Sumatera Barat

Tahun 2013-2015

\begin{tabular}{cccc}
\hline Tahun & $\begin{array}{c}\text { Laba Bersih Setelah Pajak } \\
(1)\end{array}$ & $\begin{array}{c}\text { Modal Sendiri } \\
(2)\end{array}$ & $\begin{array}{c}\text { Return On Equity } \\
(1: 2) \times 100 \%\end{array}$ \\
\hline 2013 & Rp 312.725 & Rp 2.000.000 & $15,63 \%$ \\
2014 & Rp 293.793 & Rp 2.000.000 & $14,68 \%$ \\
2015 & Rp 317.279 & Rp 2.000.000 & $15,86 \%$
\end{tabular}

Sumber : Data Hasil Olahan

Dari tabel diatas, perkembangan NPM (Net Profit Margin) PT. BPD Sumatera Barat mengalami penurunan yang signifikan. Laba bersih setelah pajak tahun 2013 sebanyak Rp. 312.725 dengan pendapatan operasional sebanyak Rp. 1.855.250 dan pada tahun 2014 laba bersih setelah pajak Rp. 293.793 dengan pendapatan operasional Rp. 2.078.547, sedangkan pada tahun 2015 agak terjadi peningkatan dari tahun sebelumnya dengan laba bersih setelah pajak Rp. 317.279 dengan pendapatan operasional Rp. 2.265.374. Dari tabel di atas dapat disimpulkan bahwa net profit margin Bank Pembangunan Daerah (BPD) Sumatera Barat mengalami penurunan dan peningkatan pada tiap tahunnya. Sedangkan persentase net profit margin dari tahun 2013-2015 termasuk dalam kategori baik yang mencapai rata-rata industri yaitu sebesar 3,92\%.

Dari tabel perhitungan Return On Asset pada PT. BPD Sumatera Barat diatas dapat dilihat laba sebelum pajak pada tahun 2013 sebesar Rp. 432.321 dengan total asset sebesar Rp. 16.244.113 dan pada tahun 2014 dengan laba sebelum pajak sebesar Rp. 348.247 dan total asset sebesar Rp. 18.014.579, sedangkan pada tahun 2015 dengan laba sebelum pajak sebesar Rp. 446.825 dengan total asset sebesar Rp. 19.448.300. Jika dilihat dari persentase perhitungan Return On Asset dari tahun 2013-2015 tidak terjadi perubahan yang signifikan yaitu pada tahun 2013 dengan persentase $2,65 \%$ dan terjadi penurunan pada tahun 2014 yaitu sebesar 1,93\%, dan pada tahun 2015 persentasenya naik menjadi sebesar 2,29\%. Dari penjelasan diatas, dapat disimpulkan bahwa Bank Pembangunan Daerah (BPD) Sumatera Barat dari tahun 2013-2015 belum mencapai tingkat keuntungan yang baik jika dilihat dari rata-rata industri yang persentasenya sebesar 5,08\%. Hal ini menyimpulkan bahwa perusahaan tidak bisa memanfaatkan asset yang dimiliki perusahaan dengan baik.

Jika dilihat dari tabel perhitungan Return On Equity pada PT. BPD Sumatera Barat tahun 2013 dengan laba bersih setelah pajak yaitu sebesar Rp. 321.725 dengan modal sendiri sebesar Rp. 2.000.000, dan pada tahun 2014 laba bersih setelah pajak yaitu sebesar Rp. 293.793 dan modal sendiri sebesar Rp. 2.000.000, sedangkan pada tahun 2015 laba bersih setelah pajak yaitu sebesar Rp. 317.279 dan modal sendiri yaitu sebesar Rp. 2.000.000. Jika dilihat dari persentase perhitungan ROE maka dapat disimpulkan bahwa Bank Pembangunan Daerah (BPD) Sumatera Barat mendapatkan laba yang maksimal dari modal yang dimiliki sendiri. 


\section{SIMPULAN}

Berdasarkan uraian penjelasan tentang analisis tingkat rentabilitas pada hasil dan pembahasan yang dikemukakan pada bab sebelumnya, maka dapat disimpulkan analisis laporan keuangan pada PT. BPD Sumatera Barat dilihat dari rasio rentabilitas adalah sebagai berikut :

1. Secara umum efisiensi perusahaan mengalami penurunan pada tahun 2014 dan 2015.

2. Efektifitas manajemen dari tahun 2013 ke tahun 2014 dan 2015 menurun signifikan terutama pada ROA hingga dibawah standar BI.

3. Kemampuan perusahaan dalam menghasilkan laba bersih di tahun 2013 menunjukkan kemampuan yang baik dibandingkan di tahun 2014 dan 2015 yang mengalami penurunan yang cukup signifikan dari tahun sebelumnya.

4. Kemampuan perusahaan dalam menghasilkan laba dari operasi pengembalian modal pada tahun 2013, 2014 dan 2015 sangat efisien karena nilai ROE pada tahun 2013, 2014, dan 2015 diatas standar Bank Indonesia.

\section{DAFTAR PUSTAKA}

Abdullah, Faisal. (2003). Manajemen Perbankan (Teknik Analisis Kinerja Keuangan Bank). Universitas Muhammadiyah Malang (UMM) Press Malang.

Afriyeni, A. Fernos, J (2018). Analisis Faktor-Faktor Penentu Kinerja Profitabilitas Bank Perkreditan Rakyat (BPR) Konvensional Di Sumatera Barat. Jurnal Benefita: Ekonomi Pembangunan Manajemen Bisnis Dan Akuntansi. Volume 3. No. 3. http://doi.org/10.22216/jbe.v3i3.3623

Arifin, I. Z., \& Marlius, D. (2017). Analisis Kinerja Keuangan PT. Pegadaian Cabang Ulak Karang. https://doi.org/10.31227/osf.io/n2peu

Bank Indonesia,”Analisa Laporan Keuangan Perbankan”, BI, Yogyakarta, 1996.

Djahidin, 1983, Analisa Laporan Keuangan. Ghalia Indonesia, Jakarta. Harmanto, 1984, Analisis Kinerja Dan Perencanaan Keuangan Perusahaan. Edisi Pertama, BPFE Yogyakarta.

Djarwanto, 2004. Pokok-Pokok Analisis Laporan Keuangan, edisi kedua, Gadjah Mada, BPFE, Yogyakarta.

Hanafi, Mamduh dan Abdul Halim,"Analisis Laporan Keuangan”, AMP-YKPN, Jakarta, 2003

Hardi, J., \& Fernos, J. (2019). Analisis LDR Dan NPL PT. Bank Nagari Cabang Pembantu Tarusan Kabupaten Pesisir Selatan. https://doi.org/10.31227/osf.io/5dtm7 
Iswari, M., \& Fernos, J. (2019). Analisis Tingkat Kesehatan Bank Pada PT. Bank Pembangunan Daerah Sumatera Barat. https://doi.org/10.31227/osf.io/ja7ty

Handayani, M., \& Marlius, D. (2017). Analisis Tingkat Kesehatan PT. BPR Batang Kapas. https://doi.org/10.31227/osf.io/bq48z

K. R. Subramanyam dan John J. Wild. 2010. “Analisa Laporan Keuangan (Financial Statement Analysis). Edisi 10. Salemba Empat

Kasmir. 2008. Bank dan Lembaga Keuangan Lainnya. Jakarta: Rajawali Pers.

Kasmir. 2008. Analisis Laporan Keuangan. Jakarta: Rajawali Pers.

Munawir, 2000. Analisa Laporan Keuangan, edisi keempat. Liberty, Yogyakarta.

Teguh Pudjumuijono, Analisis Laporan Keuangan Untuk Perbankan. Edisi Revisi, 1999. Penerbit Djambatan, Jakarta, 1999.

Prihadi Toto, 2009. Analisis Rasio Keuangan. Jakarta: Penerbit PPM.

Moh Nasir. 1999. Metode Penelitian, Jakarta: PT. Ghalia Indonesia.

Munawir, S. Drs. Msc (1995), Analisa Laporan Keuangan, Edisi Keempat, Penerbit Liberti, Yogyakarta

Oktavia, L., \& Fernos, J. (2019). Analisis Laporan Keuangan Berdasarkan Tingkat Rentabilitas Bank Perkreditan Rakyat (BPR) Batang Palangki. https://doi.org/10.31227/osf.io/tbqdv

Peraturan Bank Indonesia, No. 13/1/PBI/2011, tentang Penilaian Tingkat Kesehatan Bank Umum; Jakarta

Putri, Y. A., \& Marlius, D. (2018). Analisis Tingkat Kesehatan Bank Pada PT. Bank Perkreditan Rakyat (BPR) Jorong Kampuang Tangah Pariaman Cabang Padang. https://doi.org/10.31227/osf.io/r98pv

Rahmayeli, D. S., \& Marlius, D. (2017). Analisis Kinerja Keuangan Pada PT. Bank Perkreditan Rakyat (BPR) Batang Kapas Pesisir Selatan. https://doi.org/10.31227/osf.io/sz5db

Setiani, Hertani.2012. Analisis Laporan Keuangan Rentabilitas dan Solvabilitas. Gunadarma

Suherti, E., \& Fernos, J. (2019). Analisa Rasio Terhadap Laporan Keuangan Pada PT. Bank Pembangunan Daerah Sumatera Barat. https://doi.org/10.31227/osf.io/9zte8 